WARSZTATY Z GEOGRAFII TURYZMU

ISBN 978-83-7525-713-7 s. 221-234

http://dx.doi.org/10.18778/7525-713-7.13

Mateusz ROGOWSKI

Usługi Turystyczne i Edukacyjne, Zaniemyśl

\title{
ATRAKCYJNOŚĆ TURYSTYCZNA SZLAKÓW PIESZYCH - METODA OCENY
}

\begin{abstract}
Wstęp
Dynamiczny rozwój turystyki w XX w. jest najważniejszym dowodem zmian cywilizacyjnych związanych z coraz dłuższym czasem wolnym od pracy. Wiąże się z tym rosnąca potrzeba aktywnego wypoczynku na obszarach o atrakcyjnych walorach. Do najbardziej popularnych form zaliczana jest turystyka piesza będącą najczęściej podejmowaną formą penetracji rekreacyjnej (SIEVALNEN, KNOPP 1992, STYPEREK 2001). Jej powszechność potwierdza fakt jej występowania niemalże w każdym zakątku naszego kraju, ze szczególnym uwzględnieniem obszarów chronionych. Jest najlepszym sposobem poznania przyrody, krajobrazów, zabytków, kultury ludowej oraz życia mieszkańców. Dużą zaletą wędrówek pieszych jest też możliwość wyboru tras z dala od przepełnionych turystami ośrodków. Istotne są też walory zdrowotne turystyki pieszej, gdyż korzystnie oddziałują na organizm ludzki powodując wzmocnienie sił psychofizycznych (KUREK 2007).

Czynnikiem ułatwiającym uprawianie turystyki pieszej są szlaki turystyczne oznaczone najczęściej wzdłuż dróg i ścieżek za pomocą zunifikowanych znaków. Szlaki piesze są ważnym elementem infrastruktury turystycznej obszaru, a szczególnie istotną rolę odgrywają w regionach turystycznych
\end{abstract}


i na obszarach chronionych o najwyższym statusie. To właśnie $\mathrm{w}$ tych miejscach zarówno udostępniaja jak również chronią walory turystyczne przed degradacją. Ich znaczenie podkreślają zgodnie KRAKOWIAK (1997), STYPEREK (2002), STASIAK (2006) oraz STAFFA (2007), zaliczając je do podstawowych i najważniejszych elementów zagospodarowania turystycznego umożliwiającego zdaniem WARSZYŃSKIEJ i JACKOWSKIEGO (1978), korzystanie $\mathrm{z}$ walorów turystycznych.

\section{Stan badań}

W dobie intensywnego rozwoju pieszego ruchu turystycznego zagadnienie oceny atrakcyjności turystycznej szlaków pieszych jest bardzo ważne i wielopłaszczyznowe. Spowodowane jest to głównie powszechnością szlaków turystyki pieszej, co związane jest $\mathrm{z}$ różnorodnymi powiązaniami strukturalno-funkcjonalnymi otoczenia oraz specyfiką środowiska przyrodniczego i kulturowego. Dotychczasowy dorobek w literaturze przedmiotu jest dość skromny. Wśród takich opracowań można wyróżnić oceny środowiska geograficznego na potrzeby szlaków pieszych (DROBNIAK 1979, SEWERNIAK 1979, 1980a, 1980b, LOREK 2007), tradycyjne metody oceny szlaków pieszych (DEJA 1982, KUCHARSKA 2006), dróg samochodowych (WERNER 1978), wykorzystaną do oceny szlaków pieszych (KOŁODZIEJCZYK 2010) oraz metodę potencjału turystyczno-kulturowego szlaku (MIKOS V. ROHRSCHEIDT 2009). Ponadto temu celowi służą liczne formularze oceny wykonane przez służby ochrony przyrody, organizacje turystyczne i władze lokalne (Charte Rando Nature 2007, Grille d'évaluation... 2007, 2009, Méthode d'évaluation... 2009).

\section{Założenia metody oceny}

O przydatności przestrzeni do pieszego ruchu turystycznego decyduje wiele kryteriów, na które składa się zespół różnorodnych cech środowiska naturalnego (przestrzeni fizycznogeograficznej) oraz cech przestrzeni społeczno-ekonomicznej, charakteryzujących się złożoną strukturą i dużą zmiennością w czasie. Atrakcyjność turystyczna w odniesieniu do szlaku jest pojęciem złożonym, o którym według KURKA i MIKI (2007) decydują z jednej 
strony obiektywnie istniejące warunki przyrodnicze i społeczno-kulturowe, a z drugiej ich subiektywny odbiór i ocena przez uczestników ruchu turystycznego. Wynika ona z zespołu cech przyrodniczych i pozaprzyrodniczych, które wzbudzają zainteresowanie i przyciągają turystów. Pojęcie to, zdaniem KURKA i MIKI (2007), zawiera w sobie elementy stanowiące podstawę rozwoju wszelkiej aktywności turystycznej i zaspokajania potrzeb turystycznych, jakimi są według LIJEWSKIEGO, MIKUŁOWSKIEGO i WYRZYKOWSKIEGO (2002): ranga walorów turystycznych, dostępność komunikacyjna i możliwość obsługi urządzeń turystycznych. Na walory turystyczne składają się zróżnicowane cechy i elementy środowiska geograficznego zlokalizowane w sąsiedztwie szlaku, które są postrzegane przez turystę. O dostępności komunikacyjnej decydują możliwości dojścia lub dojazdu publicznymi środkami komunikacji drogowej i kolejowej, a także własnym środkiem transportu. Ostatnią grupe tworzą obiekty bazy noclegowej i gastronomicznej, a także wszelkie urządzenia rozmieszczone wzdłuż szlaku.

Istotną trudnością w ocenie atrakcyjności turystycznej szlaków pieszych jest jednoczesne uwzględnienie elementów przyrodniczych i antropogenicznych. Spowodowane jest to zachowaniem turysty będącym efektem subiektywnej oceny zasobów, na którą mają wpływ liczne uwarunkowania psychologiczne, kulturowe i ekonomiczne, co wyklucza ujęcie obiektywne. Nie oznacza to jednak, że należy zrezygnować z prób obiektywizacji procesu waloryzacji zasobów turystycznych, a jedną z nich jest ujęcie systemowe odnoszące się do ujęcia kompleksowego (KOWALCZYK 2000). Inną próbą obiektywizacji jest odniesienie oceny do opinii samych użytkowników przedmiotu oceny, do których w niniejszej pracy zalicza się turystów i przewodników.

Kolejnym problemem jest ocena walorów naturalnych, która metodycznie jest zadaniem trudnym, bowiem przedmiotem analiz są elementy środowiska, a więc cechy jakościowe należące do kategorii "niemierzalnych" (WARSZYŃSKA, JACKOWSKI 1978). Ponadto w przypadku ocen kompleksowych krajobrazu istnieją trudności metodyczne $\mathrm{z}$ agregacją poszczególnych zbiorów cech określających odrębne składniki krajobrazu. Przeszkoda ta w ciągu kolejnych kilkudziesięciu lat nie została wyeliminowana i według LIJEWSKIEGO, MIKUŁOWSKIEGO i WYRZYKOWSKIEGO (2002) sprowadzenie do wspólnego mianownika różnych wartości odnoszących się do różnych „jakości" (cech) tego środowiska stanowi nadal największy problem. Ponadto wszystkie oceny są obarczone pewną dozą subiektywizmu, gdyż każdy człowiek jest istotą niepowtarzalną, reagującą w sposób indywidualny na bodźce zewnętrzne.

Metoda oceny atrakcyjności turystycznej szlaków pieszych została opracowana w oparciu o studia literaturowe i liczne konsultacje naukowe 
z przedstawicielami różnych dziedzin, z uwzględnieniem weryfikacji na kilkunastu przykładach szlaków pieszych zlokalizowanych w różnych częściach Dolnego Śląska. Wstępne założenia metody przedstawiono w osobnych opracowaniach (ROGOWSKI 2008), w których dokonano próby oceny walorów krajobrazowych i widokowych szlaku (ROGOWSKI 2009) oraz fragmentu sieci szlaków pieszych w Karkonoskim Parku Narodowym (RoGOWSKI 2010) przy wykorzystaniu narzędzi GIS (ROGOWSKI 2011b). Na ustalenie kryteriów oceny duży wpływ miały wyniki badań ankietowych wśród przewodników i wywiadów kwestionariuszowych wśród turystów na szlaku, przedstawione $\mathrm{w}$ ubiegłorocznej publikacji zatytułowanej Turystyka polska w latach 1989-2009 z serii „Warsztaty z Geografii Turyzmu” (ROGOWSKI 2011a).

Elementy i czynniki składające się na procedurę oceny zostały zestawione w 22 kryteria podzielone na trzy grupy (rys. 1).

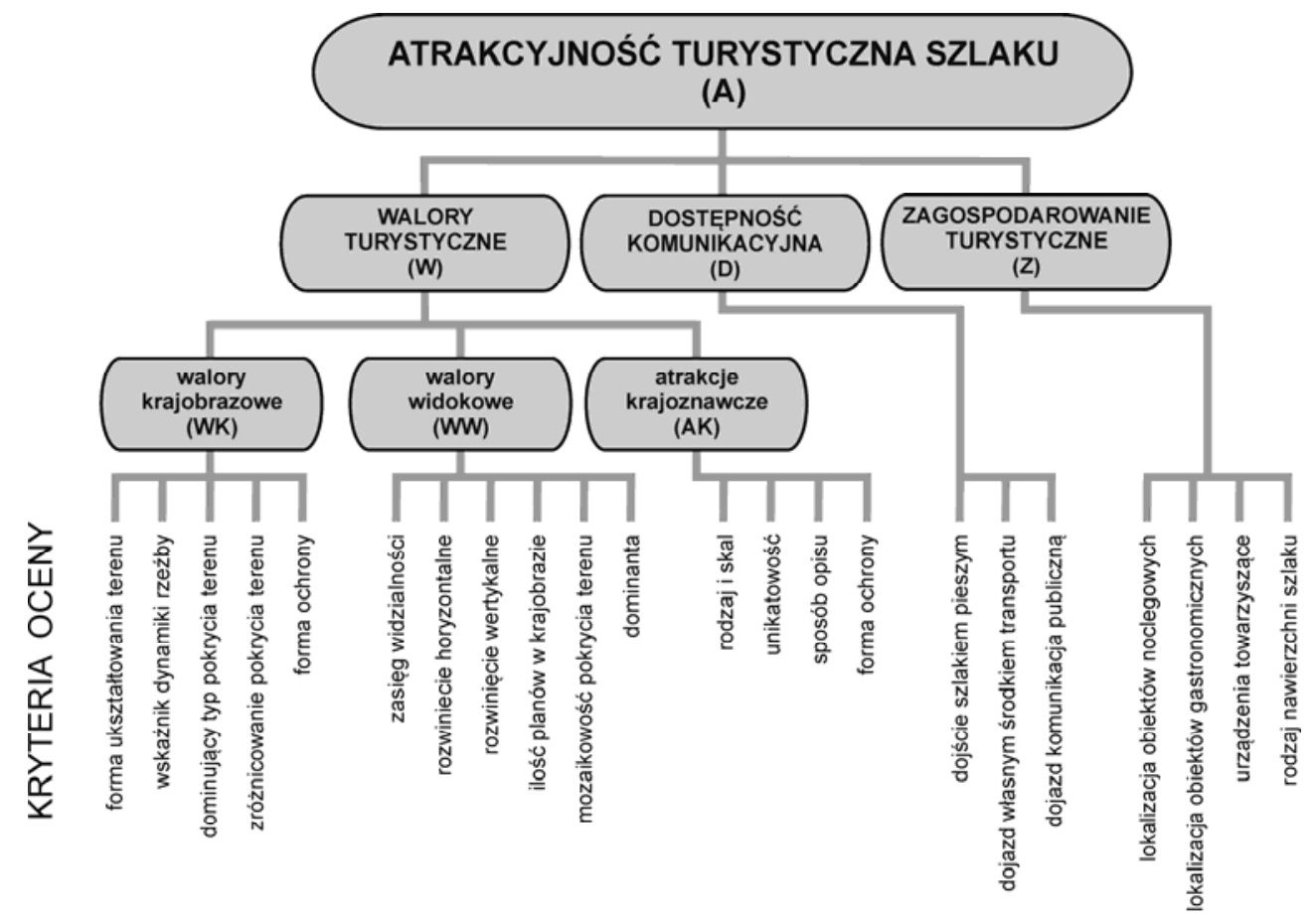

Rys. 1. Kryteria oceny atrakcyjności turystycznej szlaku pieszego Źródło: opracowanie własne 
Odcinek szlaku o długości $1 \mathrm{~km}$ jest oceniany pod względem każdego $\mathrm{z}$ możliwych do zastosowania kryterium punktacją w przedziale od 1 do 4 lub - w przypadku zagospodarowania turystycznego - od 1 do 3. Po zsumowaniu punktów odcinek zostaje przyporządkowany do jednego z czterech przedziałów, którym przypisywane są tzw. „duże” punkty odnoszące się do nasycenia cechy małego (I pkt), umiarkowanego (II), dużego (III) i wybitnego (IV). Procedura ta odbywa się kolejno dla walorów krajobrazowych, widokowych i atrakcji krajoznawczych, potem ponownie w ten sam sposób dla walorów turystycznych, następnie dla dostępności komunikacyjnej i zagospodarowania turystycznego.

\section{Kryteria oceny}

Każdy odcinek szlaku, zgodnie z definicją atrakcyjności turystycznej (wg LIJEWSKIEGO, MIKUŁOWSKIEGO i WYRZYKOWSKIEGO 2002), oceniany jest pod względem walorów turystycznych (W), dostępności komunikacyjnej (D) i zagospodarowania turystycznego (Z). Punktacja dla poszczególnych kryteriów została przedstawiona w tab. 1.

Tabela 1. Przedziały atrakcyjności turystycznej szlaków pieszych

\begin{tabular}{|c|c|}
\hline $\begin{array}{c}\text { Przedziały punktacji oceny } \\
\text { atrakcyjności turystycznej szlaku } \\
(\mathrm{PKT})\end{array}$ & Słowna ocena szlaku \\
\hline $2,0-5,0$ & mało atrakcyjny \\
\hline $5,1-8,0$ & umiarkowanie atrakcyjny \\
\hline $8,1-11,0$ & atrakcyjny \\
\hline$>11,0$ & wybitnie atrakcyjny \\
\hline
\end{tabular}

Źródło: opracowanie własne.

Na walory turystyczne (W) składają się różnorodne cechy środowiska naturalnego oraz atrakcje przyrodnicze i kulturowe oceniane w oparciu o 15 kryteriów podzielonych na trzy grupy: walory krajobrazowe (WK), walory widokowe (WW) i atrakcje krajoznawcze (AK). Pierwsze z nich (WK) wynikają $\mathrm{z}$ przebiegu szlaku $\mathrm{w}$ przestrzeni geograficznej i stanowią syntezę wszystkich elementów przyrodniczych i antropogenicznych będących we 
wzajemnym stosunku i oddziaływaniu. Ocena odbywa się w oparciu o pięć kryteriów odnoszących się do poszczególnych odcinków:

1) przebieg $\mathrm{w}$ obrębie formy ukształtowania terenu (na potrzeby metody wyróżniono cztery grupy form $\mathrm{w}$ trzech strefach krajobrazowych - górskiej, wyżynnej i nizinnej - przy uwzględnieniu zróżnicowania wewnętrznego oraz stopnia odmienności w stosunku do otoczenia);

2) dynamika rzeźby wyrażona wzorem H. Steinhausa (1947, za: GADZOJANIS 1977), odnosząca się do liczby pokonywanych różnic wysokości (suma podejść i zejść);

3) fizjonomiczna naturalność pokrycia terenu według opinii turystów, im bardziej dany typ pokrycia jest zbliżony do naturalnego, tym jego walory krajobrazowe są bardziej atrakcyjne;

4) zróżnicowanie pokrycia terenu określone liczbą wydzieleń po jednej lub obu stronach szlaku (rys. 2);

5) przebieg w obrębie powierzchniowych form ochrony przyrody walorów krajobrazowych.
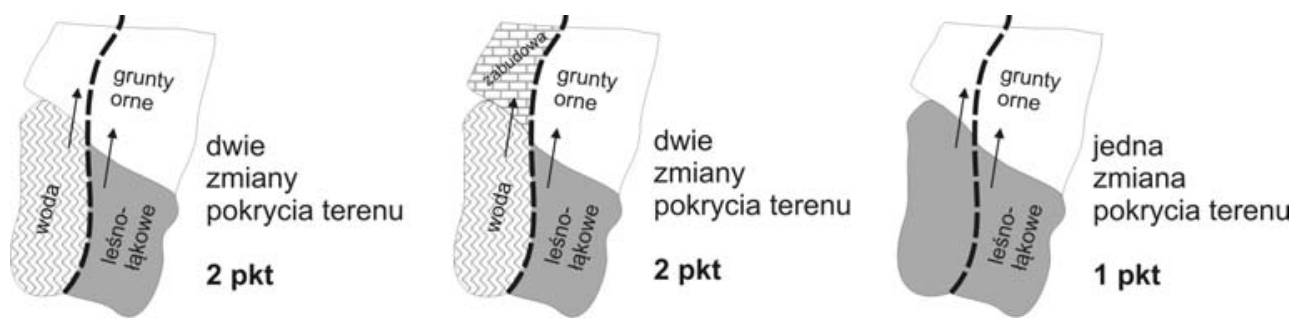

Rys. 2. Sposoby określania liczby zmian pokrycia terenu wzdłuż szlaku Źródło: opracowanie własne

Walory widokowe (WW) odnoszą się do panoram z punktów widokowych zlokalizowanych wzdłuż szlaku. Cechuje je zmienność w zależności od miejsca obserwacji oraz nieciaggłość, gdyż miejscem obserwacji jest punkt lub odcinek szlaku. Ich ocenę przeprowadzono w oparciu o sześć kryteriów:

1) zasięg widzialności określający odległość z punktu obserwacji do najdalszego widocznego obiektu topograficznego wyrażony w kilometrach;

2) kąt widoczności poziomej, czyli szerokość rozwinięcia horyzontalnego panoramy, której rozpiętość pozwala na ogląd terenu otaczającego punkt widokowy (rys. 3);

3) kąt widoczności pionowej, tj. wysokość rozwinięcia wertykalnego panoramy, określany jako kąt między kierunkiem na najwyższy widoczny punkt a linią spadku stoku, z którego prowadzona jest obserwacja (rys. 4); 
4) liczbę planów w panoramie, wyznaczonych załomami terenu oraz liniami lasów i drzew;

5) mozaikowością pokrycia terenu, wyrażoną liczbą wydzieleń w obserwowanej panoramie;

6) dominantami, będącymi elementami topograficznymi najwyższymi w całej kompozycji panoramy.

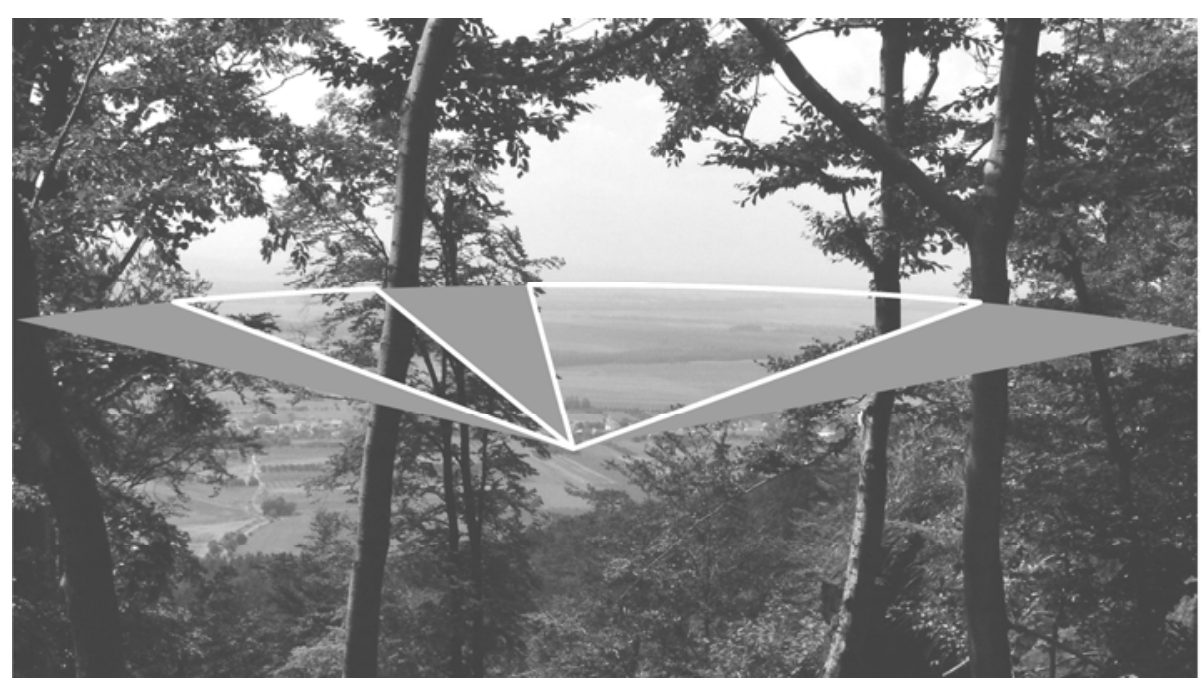

Rys. 3. Kąt widoczności poziomej ukazujący fragment panoramy Źródło: opracowanie własne

Obliczenie kąta widoczności pionowej wykonuje się za pomocą funkcji trygonometrycznych. Szukany kąt $(A B C)$ jest sumą dwóch innych wyznaczonych między najwyższym i najniższym punktem $\mathrm{w}$ panoramie a punktem obserwacji $(A B D$ i $E B C)$.

$$
\Varangle A B C=\Varangle A B D+\Varangle E B C
$$

Uzyskanie jego wartości kątowej możliwe jest po zsumowaniu wartości sinusów obu składowych kątów.

$$
\sin \Varangle A B C=\sin \Varangle A B D+\sin \Varangle E B C
$$

W obrazie panoramy należy odnaleźć najwyższy i najniższy punkt ograniczający rozwinięcie i określić ich wysokości bezwzględne. Znając wysokość bezwzględną punktu obserwacji należy obliczyć różnicę wysokości między nimi $(A-B$ oraz $B-C)$ oraz odległość w linii prostej. Uzyskane war- 
tości podstawiamy do domyślnie utworzonych trójkątów prostokątnych. Korzystając z wzoru na sinus kąta obliczamy ich wartości, a następnie sumujemy je ze sobą uzyskując sinus kąta rozwinięcia horyzontalnego.

$$
\begin{aligned}
\sin \searrow A B D= & \frac{|A-B|}{d} \quad \sin \rtimes E B C=\frac{|B-C|}{e} \\
& \sin \searrow A B C=\left(\frac{|A-B|}{d}\right)+\left(\frac{|B-C|}{e}\right)
\end{aligned}
$$

Wartość kątową rozwinięcia wertykalnego odczytujemy z tablic matematycznych.

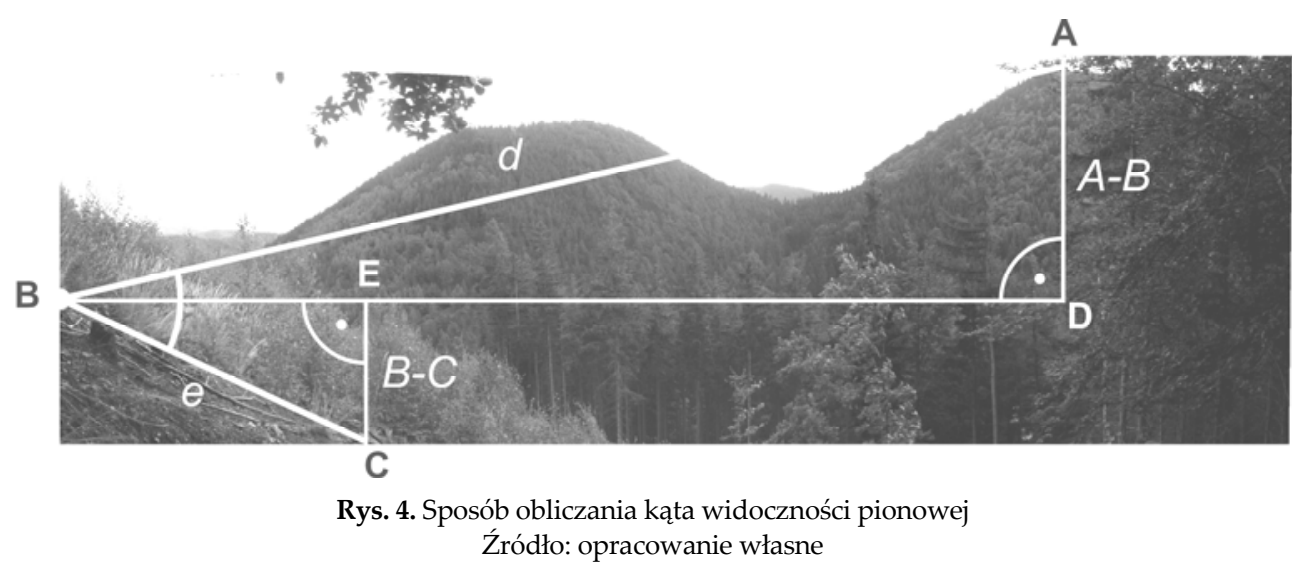

Kryteria oceny atrakcji krajoznawczych (AK) zostały opracowane w oparciu o trzy cechy: rodzaj, wartość i nasycenie. Podstawą do sporządzenia listy atrakcji jest ich oznaczenie na mapie turystycznej i opis $\mathrm{w}$ reprezentatywnym przewodniku po regionie. $W$ przypadku ich braku odcinek uzyskuje 0 pkt. Oceny dokonuje się w oparciu o cztery kryteria:

1) rodzaj i skalę atrakcji, o której decydują wartości poznawcze, naukowe i dydaktyczne obiektu mające wpływ na jej popularność wśród turystów;

2) unikatowość występowania w przestrzeni geograficznej odnoszącej się do niepowtarzalności w stosunku do innych atrakcji;

3) charakter opisu krajoznawczego atrakcji w reprezentatywnej literaturze przewodnikowej oraz oznaczenie na mapie turystycznej;

4) formę ochrony, którą objęta została atrakcja krajoznawcza w celu zachowania jej szczególnej wartości i unikatowości. 
W ocenie walorów krajobrazowych (WK) i widokowych (WW) każdy odcinek uzyskuje określoną liczbę punktów będącą sumą poszczególnych kryteriów. Dla walorów krajobrazowych punktacja mieści się w przedziale od 4 (po 1 pkt. dla pierwszych czterech kryteriów) do 20 pkt. (maksymalna punktacja dla wszystkich kryteriów). W przypadku walorów widokowych odcinek może uzyskać od 5 (po 1 pkt. dla pierwszych pięciu kryteriów) do 21 pkt. (maksymalna punktacja dla pięciu kryteriów i 1 pkt dla szóstego). Następnie każdemu odcinkowi przyznawane są "duże” punkty za walory krajobrazowe i widokowe odzwierciedlając ich atrakcyjność. Minimalna punktacja dla atrakcji krajoznawczych (AK), jaką uzyskuje odcinek, to 3 pkt. (po 1 pkt. dla pierwszych trzech kryteriów) za istnienie jednej najmniejszej atrakcji turystycznej o unikatowości w skali lokalnej, oznaczonej wyłącznie na rewersie mapy turystycznej regionu. Przedziały punktowe zostały utworzone $\mathrm{w}$ ten sposób, aby jednocześnie uwzględniały punktacje dla atrakcji oraz ich nasycenia i dlatego wzrastają proporcjonalnie.

Końcowa ocena walorów turystycznych (W) polega na zestawieniu „dużych" punktów dla walorów (WK, WW) i atrakcji (AK). Punktacja ta oscyluje pomiędzy I a XII, za którą przydzielane są „duże” punkty dla walorów turystycznych (W I, W II, W III, W IV), odzwierciedlając ich całościową atrakcyjność.

W przypadku dostępności komunikacyjnej (D) zapewniającej turystom możliwość dotarcia do szlaku różnymi środkami lokomocji, ocena dokonywana jest w oparciu o trzy kryteria:

1) możliwość dotarcia innymi szlakami pieszymi i ścieżkami dydaktycznymi określana liczbą kierunków, z których można dojść do wybranego odcinka (rys. 5);

2) możliwość dojazdu własnym środkiem transportu przy wykorzystaniu sieci dróg jezdnych znajdujących się przy szlaku lub w jego 30-minutowej izochronie pieszej;

3) możliwość dojazdu komunikacją publiczną uwzględniającą liczbę i jakość połączeń z dworca, stacji lub przystanku autobusowego i kolejowego oraz przystanku tramwajowego znajdujących się przy szlaku lub w jego 30-minutowej izochronie pieszej (w przypadku wyciagu krzesełkowego i kolejki linowej określona została jednakowa punktacja).

Gdy brak możliwości bezpośredniego dotarcia do odcinka, wówczas uzyskuje on 0 pkt i można się do niego dostać wyłącznie wykorzystując sąsiednie odcinki.

W końcowej ocenie dostępności komunikacyjnej (D) każdy odcinek uzyskuje określoną liczbę punktów (z przedziału od 1 do 16 pkt.) będącą sumą punktów poszczególnych kryteriów. W dalszej kolejności przyznawane są 
"duże" punkty zgodnie z równymi przedziałami, odzwierciedlając stopień dostępności komunikacyjnej odcinka szlaku (DI, DII, DIII, DIV).

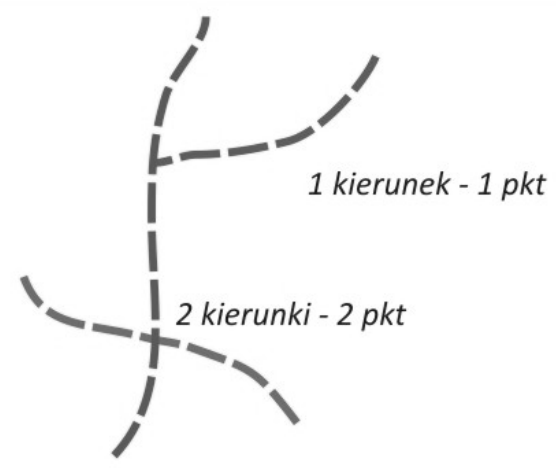

Rys. 5. Rodzaje skrzyżowań szlaków pieszych i związanych z nimi kierunków dojścia Źródło: opracowanie własne

Ostatnią składową jest stan przystosowania terenu do obsługi ruchu turystycznego określony mianem zagospodarowania turystycznego (Z). Zaspokaja ono potrzeby związane z noclegiem, wyżywieniem oraz bezpośrednią obsługą turystów na szlaku, co charakteryzują poszczególne jego funkcje. Na potrzeby oceny stworzono cztery kryteria oceny:

1) wyposażenie $\mathrm{w}$ obiekty noclegowe uwzględniające ich lokalizacje w stosunku do szlaku;

2) wyposażenie w obiekty gastronomiczne, również biorąc pod uwagę ich lokalizację w stosunku do szlaku (oceną objęto wyłącznie punkty gastronomiczne w obiektach ogólnodostępnych, a wyeliminowano kuchnie samoobsługowe w schroniskach i kwaterach prywatnych, gdyż umożliwiają jedynie przyrządzanie posiłków we własnym zakresie);

3) stopień wyposażenia i nasycenia obiektami towarzyszącymi o różnorodnych funkcjach (najczęściej informacyjna, edukacyjną i rekreacyjną);

4) dominujący rodzaj nawierzchni szlaku determinujący komfort marszu.

W końcowej ocenie zagospodarowania turystycznego (Z) każdy odcinek szlaku uzyskuje określoną punktację będącą sumą czterech kryteriów. Liczba punktów mieści się $\mathrm{w}$ przedziale od 1 (1 pkt dla jednego kryterium, przy braku punktacji w pozostałych) do 12 pkt. (maksymalna punktacja dla wszystkich kryteriów). Następnie przyznawane są „duże” punkty zgodnie 
z równymi przedziałami, odzwierciedlając stan zagospodarowania turystycznego odcinka szlaku (ZI, ZII, ZIII, ZIV).

Końcowa ocena atrakcyjności turystycznej odcinka szlaku polega na zestawieniu „dużych" punktów za walory turystyczne (WI, WII, WIII, WIV), dostępność komunikacyjną (DI, DII, DIII, DIV) i zagospodarowanie turystyczne (ZI, ZII, ZIII, ZIV). Każdy odcinek uzyskuje punktację z przedziału od I do XII pkt. Następnie punkty te przeliczane są przez wskaźnik wagowy dla poszczególnych składowych, ustalony w oparciu o studia literatury, opinie specjalistów, przewodników oraz turystów i wynosi:

- 2 dla walorów turystycznych (Wsk. $W$ ), stanowiąc $50 \%$ oceny,

- 1 dla dostępności komunikacyjnej (Wsk. D), stanowiąc 25\% oceny,

- 1 dla zagospodarowania turystycznego (Wsk. Z), stanowiąc $25 \%$ oceny.

$$
A T_{\text {odcinka }}=W \times 2+D \times 1+Z \times 1
$$

Uzyskane w ten sposób wartości określają atrakcyjność turystyczną podzieloną na cztery przedziały:

- AI: odcinek mało atrakcyjny turystycznie,

- AII: odcinek umiarkowanie atrakcyjny turystycznie,

- AIII: odcinek atrakcyjny turystycznie,

- AIV: odcinek wybitnie atrakcyjny turystycznie.

Końcowa ocena atrakcyjności turystycznej szlaku pieszego polega na obliczeniu średniej wartości dla wszystkich odcinków, co determinuje równoważność odcinków w ocenie.

$$
A T_{\text {szlaku }}=\sum_{i=0}^{n} A
$$

gdzie:

$A T$ - ocena atrakcyjności turystycznej odcinka.

\section{Podsumowanie}

Przedstawiona metoda oceny atrakcyjności szlaków pieszych została zweryfikowana w oparciu o kilkanaście szlaków pieszych zlokalizowanych w różnych krajobrazach Dolnego Śląska - począwszy od terenów płaskich den dolinnych, przez pagórkowate, góry niskie, średnie i wysokie typu sudeckiego (WYRZYKOWSKI 1991). Stopień i możliwość dostępności komunikacyjnej szla- 
ków oraz stan ich zagospodarowania turystycznego były zróżnicowane. Pomimo różnorodnych przykładów i analiz widoczne są niedoskonałości metody, które w przyszłości należałoby wyeliminować uwzględniając poniższe zagadnienia:

- w ocenie walorów krajobrazowych powinno uwzględnić się i dowartościować atrakcyjne krajobrazowo formy kontrastowe w ukształtowaniu terenu;

- $\quad$ w ocenie walorów widokowych należy stworzyć najwyżej punktowaną kategorię panoram dookólnych (o kącie pełnym) w kryterium rozwinięcia poziomego, gdyż są one najatrakcyjniejsze;

- w ocenie bazy noclegowej i gastronomicznej można uwzględnić inne cechy tych obiektów, takie jak rodzaj, wielkość czy standard obiektu;

- w przypadku nawierzchni szlaku należałoby także wziąć pod uwagę podłoże zerodowane oraz strefy rozdeptane, gdyż nie jest to bez znaczenia dla atrakcyjności turystycznej.

Wymienione mankamenty metody nie są jednak na tyle ważne, by istotnie zmienić końcową ocenę odcinka i szlaku. Punktacja uzyskana w wyniku zastosowania metody potwierdza, że odcinki i szlaki, które uzyskały najwyższą punktację są faktycznie najpopularniejsze i najatrakcyjniejsze. $Z$ tego względu przedstawione sugestie uzupełniają raczej tę metodę badawczą.

\section{BIBLIOGRAFIA}

Charte Rando Nature, 2007, Plan Départamental des Itinéraires de Promenade et de Randonnée (P.D.I.P.R.), Comité Départemental de Tourisme Equestre de Haute-Savoie, Conseil Générale Haute-Savoie ; http://www.cg74.fr/download/site-principal /document/actions/ amenagement/randonnee/Charte_Rando.pdf (23.08.2010 r.).

DejA W., 1982, Metoda oceny atrakcyjności turystycznej pieszych szlaków turystycznych na przykładzie województwa koszalińskiego, "Jantarowe Szlaki”, XXV, (185).

DROBNIAK J. 1979, Ocena środowiska geograficznego wyspy Wolin dla potrzeb turystyki pieszej, [w:] Ocena atrakcyjności środowiska geograficznego dla potrzeb turystyki i rekreacji na różnych poziomach i etapach planowania - materiaty z konferencji, Serie i Monografie, AWF Poznań, 16.

Grille d'évaluation d'un itinéraire de randonnée VTT etéquestre (montée et/ou a ttelée) candidat à l'inscription au PDIPR, 2009, Parc naturel régional Loire Anjou Touraine, Comité Départamental du tourisme de l'Anjou ; http://www.parc-loire-anjou-touraine.fr/ parc_naturel_ regional_loire_anjou_touraine.html?lang=FRA (23.08.2010 r.).

Grille d'évaluation pour l'inscription d'un sentier pédestre au PDIPR, 2007, Randonnées en Finistère, Conseil Générale Finistère; http://www.cg29.fr/content/download/22320/ 217406/file/fiche_13.pdf (23.08.2010 r.).

KOWALCZYK A., 2000, Geografia turyzmu, PWN, Warszawa. 
KOŁODZIEJCZYK K., 2010, Atrakcyjność turystyczna szlaków pieszych Gór Rychlebskich, mpis pracy magisterskiej, Instytut Geografii i Rozwoju Regionalnego, Uniwersytet Wrocławski, Wrocław.

KRAKOWIAK B., 1997, Zagospodarowanie turystyczne karpackich parków narodowych, „Turyzm”, 7 (2).

KUCHARSKA M., 2006, Nowa metoda oceny atrakcyjności turystycznej szlaków pieszych na przykładzie szlaków pieszych oddziału łódzkiego PTTK, „,Turystyka i Hotelarstwo”, 10.

KUREK W., 2007, Turystyka piesza, [w:] W. Kurek (red.), Turystyka, Wyd. Naukowe PWN, Warszawa.

KUREK W., MiKa M., 2007, Turystyka jako przedmiot badań naukowych, [w:] W. Kurek (red.), Turystyka, Wyd. Naukowe PWN, Warszawa.

LIJEWSKI T., MIKUŁOWSKI B., WYRZYKOWSKI J., 2002, Geografia turystyki Polski, PWE, Warszawa.

LOREK D., 2007, Stan i zagospodarowanie zieleni miejskiej w zachodnim klinie Poznania jako podstawa wytyczenia szlaku turystycznego, „Badania Fizjograficzne nad Polską Zachodnią”, Seria A: Geografia Fizyczna, 58.

Méthode d'évaluation pour classer les chemins de randonnée, 2009, Formulaire d'évaluation, Délimitation des catégories de chemins de randonnée pédestre, Outil d'aide au classement, 2009, Office fédéral des routes (OFROU), Suisse Rando, Berne http://www.atse.ch /uploads/file /Categories\%20de\%20chemins\%20de\%20randonnee\% 20pedestre.pdf (23.08. 2010 r.).

MiKOS v. ROHRSCHEIDT A., 2009, Polskie szlaki turystyczno-kulturowe: kryteria i zasady waloryzacji potencjału, ,Turystyka Kulturowa”, 4, www.turystykakulturowa.org.

RoGOWSKI M., 2008, Próba określenia założeń oceny atrakcyjności turystycznej szlaków pieszych, [w:] J. Wyrzykowski (red.), Uwarunkowania rozwoju turystyki zagranicznej w Europie Srodkowej $i$ Wschodniej, t. 10: Turystyka w środowisku geograficznym, Zakład Geografii Regionalnej i Turystyki, Uniwersytet Wrocławski, Wrocław.

ROGOWSKI M., 2009, Ocena walorów widokowych krajobrazu szlaków turystycznych na wybranych przykładach z Dolnego Ślaska, „Problemy Ekologii Krajobrazu”, 25.

RoGOWSKI M., 2010, Ocena atrakcyjności turystycznej fragmentu sieci szlaków pieszych w Karkonoskim Parku Narodowym, „Opera Corcontica”, 47, Supplementum 1, Krkonosske prace, Sprava Krkonosskeho narodniho parku, Vrchlabi.

RogowsKi M. 2011a, Czynniki decydujące o atrakcyjności turystycznej szlaków pieszych w świetle opinii przewodników i turystów, [w:] B. Włodarczyk (red.), Turystyka polska w latach 19892009, „Warsztaty z Geografii Turyzmu”, Wyd. Uniwersytetu Łódzkiego, Łódź.

ROGOWSKI M., 2011b, Zastosowanie narzędzi GIS w ocenie atrakcyjności turystycznej szlaków pieszych, "Turystyka i Rekreacja. Studia i Prace”, 5, Uwarunkowania i plany rozwoju turystyki, t. V: Aspekty przyrodnicze rozwoju turystyki, Uniwersytet im. Adama Mickiewicza, Poznań.

StASIAK A., 2006, Produkt turystyczny - szlak, „Turystyka i Hotelarstwo”, 10.

SEWERNIAK J., 1979, Metoda oceny i projektowania turystycznych szlaków pieszych $w$ strefie podmiejskiej (na przykładzie Torunia), „Problemy Turystyki”, 3/5.

SEWERNIAK J., 1980a, Metoda wyznaczania szlaków turystyki pieszej w strefie nadmorskiej z uwzglednieniem ich pojemności i przepustowości, [w:] Geograficzne podstawy użytkowania turystycznego strefy nadmorskiej, Instytut Turystyki, Warszawa.

SEWERNIAK J., 1980b, Środowiska geograficzne a projektowanie szlaków turystyki pieszej w Polsce, Zeszyty Naukowe Instytutu Turystyki, Warszawa.

Sievanen T., KNOPP T.B., 1992, Outdoor Recreation in Finland and Minnesota: Integration vs Designation. Nordic Outdoor Recreation, Proceedings of the Workshop Held in Siuntio, Finland. 
STAFFA M., 2007, Szlaki i schroniska - integralne elementy zagospodarowania turystyczne w górach, [w:] Szlaki turystyczna a przestrzeń turystyczna, materiały z konferencji, Zarząd Główny PTTK, Warszawa.

STYPEREK J., 2001, Piesze szlaki turystycznej w polskich parkach narodowych, „Turyzm”, 11/1.

STYPEREK J., 2002, Linearne systemy penetracji rekreacyjnej, Wyd. Naukowe Bogucki, Poznań.

WERNER Z., 1978, Metoda oceny turystycznej wartości dróg samochodowych (na przykładzie Sudetów Kłodzkich), Zeszyty Instytutu Turystyki.

WARSZYŃSKA J., JACKOWSKI A., 1978, Podstawy geografii turyzmu, PWN, Warszawa.

WYRZYKOWSKI J. (red.), 1991, Ocena krajobrazu Polski w aspekcie fizjonomicznym na potrzeby turystyki, Zakład Geografii Regionalnej i Turystyki, Uniwersytet Wrocławski, Wrocław. 